Bolm Inst. oceanogr., S Paulo, 36(1/2):17-35, 1988

\title{
AGE AND GROWTH OF THE SOUTHEASTERN BRAZILIAN SARDINE, Sardinella
} brasiliensis, 1981-1983

Suzana Anita SACCARDO ${ }^{1}$; Carmen L. D. B. ROSSI-WONGTSCHOWSKI ${ }^{2}$; Maria Cristina CERGOLE $^{1}$ \& Maria Mercedes BITTENCOURT ${ }^{3}$

1 Superintendência do Desenvolvimento da Pesca (SUDEPE)

(Av. Indianópolis, 1123 - Indianópolis, 04063, São Paulo, SP)

2 Instituto Oceanográfico da Universidade de São Paulo

(Caixa Postal 9075, 01051 São Paulo, SP)

3 Instituto Nacional de Pesquisas da Amazônia (INPA)

(Estrada do Aleixo, 1756 - Caixa Postal 1478, 69.000, Manaus, AM)

\section{Abstract}

Brazilian sardine data were collected between September 1981 and August 1983 from the southeastern Brazilian waters. Otoliths were read using reflected ligth on the surface of the whole structure. Three methods were used to determine the time of ring formation, being the mean length per ring the best one. There are two annual rings clearly visible, one laid down in November/December, and the other one laid down in March/April. A method of age determination is described, being the maximum age 3 years.

Descriptors: Age determination, Otolith reading, Growth curves, Spawning seasons, Methodology, Sardinella brasiliensis, SW Atlantic, Brazil:

southeastern coast.

Descritores: Determinação da idade, Leitura de otölitos, Curvas de crescimento, Períodos de desova, Metodologia, Sardinella brasiliensis, At lântico Sul Ocidental, Rio de Janeiro, São Paulo, Paranä, Santa Catarina, Brasil: costa sudeste.

\section{Introduction}

Previous studies on the age and growth of the Brazilian sardine, Sardinella brasiliensis (Steindachner, 1879) have been carried out by Richardson et al. (1960). Santos \& Frantzen (1965), Rijavec et al. (1977; 1983), Vazzoler et al. (1982; 1987) and Rossi-Wongtschowski et al. (1982). The present study is part of a more extensive investigation named the "Integrated Program of

Biological Studies on Sardine", which has been developed in the southeastern coast of Brazil since 1981 to investigate changes in the biological parameters of the species, and to provide data for stock assessment.

In this paper we present the results obtained from the examination of otoliths from fish caught in four regions in the area between $22^{\circ}$ (Cabo Frio, Rio de Janeiro) and $28^{\circ} \mathrm{S}$ (Cabo de Santa Marta Grande, Santa Catarina) during the period 1981-1983.

Age was determined using an

Contr. no. 690 do Inst. oceanogr. da Usp. interpretation of rings that differs from that found in the literature, thus resulting in a new definition of the age classes. On the basis of these studies, growth parameters were estimated for the whole area for application in analytical stock assessment models.

\section{Material and methods}

Sampling was carried out during the period September 1981 to August 1983 at 13 collection points along the southeast coast of Brazil between latitudes $22^{\circ}$ and $28^{\circ} \mathrm{S}$, including four coastal states: Rio de Janeiro, São Paulo, Paraná and Santa Catarina (Fig. 1).

In order to sample the range of sizes caught, monthly samples were collected, both from commercial landings and from the artisanal fishery and consisted of $20 \mathrm{~kg}$ boxes of fish obtained from different fishing boats and various fixed nets.

After measuring all specimens sampled, subsamples stratified by $5 \mathrm{~mm}$ length groups were taken. From these each individual fish was measured for 


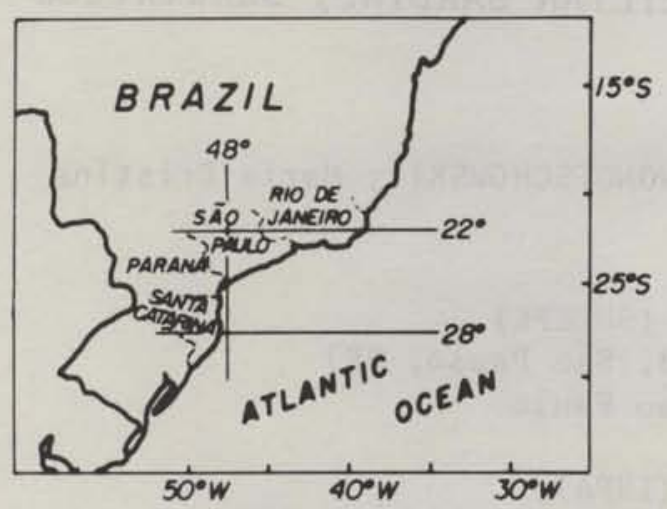

Fig. 1. Fishing ground of Brazilian sardine, Sardinella brasiliensis.

total length to the nearest millimeter, weighed to the nearest 0.1 gram $(\mathrm{g})$ and sexed; otoliths ("sagitta") were removed and stored dried for later analysis. Al1

A11 lengths given in this paper refer to total length $\left(\mathrm{L}_{t}\right)$.

A total of 287 samples containing 10,880 otoliths were obtained from the whole area in the period mentioned above.

Data on fish length and weight were analysed by region, male and female data were pooled.

The age of fish was obtained by examining whole otoliths in $70 \%$ alcohol under reflected light against a black background using a binocular stereoscopic microscope at 25 times magnification. Translucent hyaline rings were counted and measurements of various otoliths dimensions were obtained using a measuring scale in one ocular, one division corresponding to $40 \mu \mathrm{m}$.

Observations on the nature of the otolith edge, i.e., whether it was hyaline or opaque, were also made.

Two independent otoliths readings were realized, and only matched results considered.

The timing and periodicity of ring formation was verified for each region using the following methods:

a) by plotting the monthly mean length of all fish with the same number of rings on graphs and linking the points in sequence (Vazzoler, 1982);

b) monthly mean marginal growth index, as given by Matsuura (1961, cit. in: Cadwa1lader, 1978), for otoliths with 4 rings represented by: $G_{I}=R-r_{n}$ ! $R-r_{n-1}$, where $G_{I}$ is the marginal growth index, $\mathrm{R}^{\mathrm{I}}$ is the total otolith radius, and $r_{n}$ and $r_{n-1}$ are the radii of the ultimate and penultimate annulus respectively;

c) monthly frequency of hyaline and opaque edges.

Age has been interpreted according to the timing of ring formation and using the arbitrary birthday of 1st January, considering the period of the spawning peak (Matsuura, 1977; Rossi-Wongtschowski, 1977; Isaac-Nahum et al., 1988).

Growth parameters $\left(K, L_{\infty}, t_{0}\right)$ were estimated from age data for the entire area.

Growth curves were fitted by plotting $\mathrm{L}_{t}$ against $\mathrm{L}_{\mathrm{t}+1}$ using the von

Bertalanffy growth equation.

Al1 biological data were processed in FORTRAN, using a BURROUGHS 7900 System at the Electronical Computation Center of of University of São Paulo.

\section{Results}

\section{Age determination}

\section{Ring counts}

Numbers of sardine otoliths analysed by period, by region, are shown in Table 1 .

Table 1. Number of otoliths of Sardinella brasiliensis analysed during 1981-1983 from Rio de Janeiro, São Paulo, Paraná and Santa Catarina regions

\begin{tabular}{|c|c|c|c|c|}
\hline \multirow[b]{2}{*}{ Region } & \multicolumn{2}{|c|}{$81 / 82$} & \multicolumn{2}{|c|}{$82 / 83$} \\
\hline & Totel & $\begin{array}{l}\text { Natched } \\
\text { results }\end{array}$ & Totol & $\begin{array}{l}\text { Solocted for } \\
\text { onalysis }\end{array}$ \\
\hline Nio de Jeneiro & 2414 & 1644 & 2426 & 1862 \\
\hline Säo paulo & 1035 & 715 & 1114 & 1043 \\
\hline Parená & 670 & 539 & 563 & 478 \\
\hline Sente caterina & 1539 & 1019 & 1119 & 1072 \\
\hline To(e) $(10,880)$ & 5658 & 3917 & 5222 & 4455 \\
\hline
\end{tabular}


Surrounding the central nucleous two hyaline rings were often observed which were not included in the counts, because they were considered non-periodic annuli correlated with changes occurring during the larval and pre-juvenile stages, in accordance with Rossi-Wongtschowski et al. (1982). Excluding these rings, otoliths were found with 0 to 7 rings, the most frequent being 4 and 5 for Rio de Janeiro, São Paulo and Santa Catarina regions, and 2 and 3 for Paraná region. The mean lengths of $S$. brasiliensis, classified by number of rings considering both sexes together and the whole area are given in Table 2 .

\section{Periodicity of ring formation}

The monthly progression of mean lengths of specimens with the same number of rings showed that the periodical rings are formed twice a year: in November/ December, and March/April. These results can be seen in Figure 2, based on data from the whole area.

The marginal increment index value is lowest in two main periods (Fig. 3 ), viz:

$\begin{array}{lll}\text { Rio de Janeiro: Sept/Oct, Jan/Feb } \\ \text { São Paulo : Oct/Dec, } & \text { Mar/Apr } \\ \text { Santa Catarina: Oct/Dec, } & \text { Mar/May, }\end{array}$

also indicate growth checks of the same periodicity. Data from Paraná region were not considered here because otoliths with 4 rings only occurred during few months.

The analysis of the nature of the otolith edge did not give coherent results between all regions because it was often difficult to characterize it.

In general, the methods described above provided evidence of two periods of ring formation during the year, both methods indicating similar periods. As the first method described above showed that rings are formed in the same period in each of the areas studied, the times of ring formation are taken to be the months Nov/Dec and Mar/Apr for the whole area.

\section{Age class identification}

Considering data from the whole area, the sequence of monthly mean length data for fish with a given number of rings
(Fig. 2) showed that at the beginning of each year a new group of fish seems to appear in the fishery, starting its growth in length. This can be verified by the two lines approximately parallel, surging in Jan-Feb 1982, the same occurring in Jan-Feb 1983. As only one spawning peak occur in one spawning season, we consider that each two lines (two groups) represent a year-class.

As the spawning period ranges from October to March, it is possible that fish born at the beginning of this period may present two otolith rings in April, while those born at the end of the spawning period could form only one, or none till April, so causing the appearance of the two groups. We named these groups as " 1 " ( $\mathrm{fish}$ born at the beginning of the spawning period:

Sept-Nov) and "2" (fish born. subsequentely: Dec-Mar). In this work we mean year-class as the two groups combined.

So, according to the timing of ring formation and the birthday attributed to January $1^{\text {st }}$, the identification of the number of rings in the otoliths to age classes is shown in Table 3 .

In Figure 4, the same sequences of Figure 2 are shown according to the age class identification.

\section{Age structure}

On the basis of the above interpretation of ring structure, data from 1981-82 and 82-83 periods were combined, in order to obtain monthly length frequency distributions at age classes for the whole area, for each group, described as follows:

a) group "2": the youngest fish from a year-class (Table 4).

It may be verified that age- 0 fish begin to appear since January with lengths about $40 \mathrm{~mm}$ derived from the artisanal fishery in the Parana region. From March till September, fish from the commercial fishery occurred from $60 \mathrm{~mm}$ to $100 \mathrm{~mm} \mathrm{~L} \mathrm{~L}_{t}$. From October to December they practically disappeared in the catches. This group reappered, with age-I, during all the months of the next year with sizes varying from $80 \mathrm{~mm}$ (in January) to $200 \mathrm{~mm}$ (in December). At age-II sizes ranged from 150 to $230 \mathrm{~mm}$. 


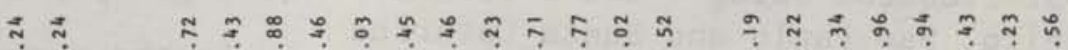

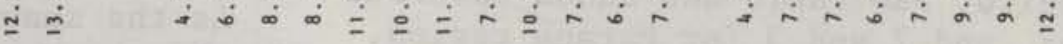

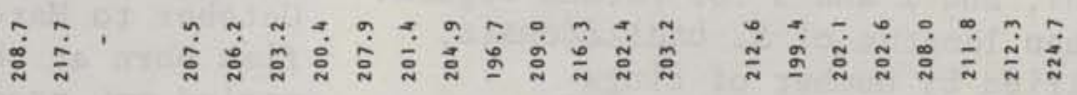

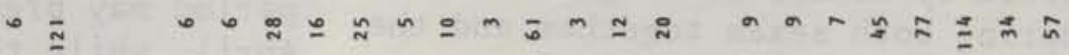

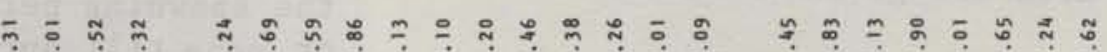

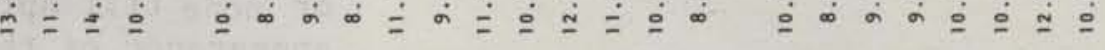

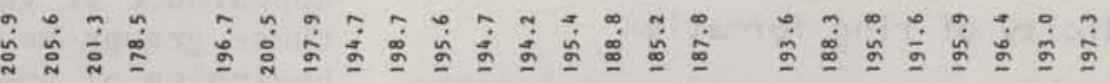

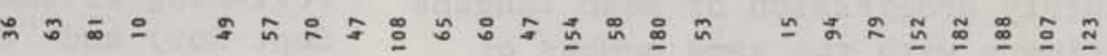

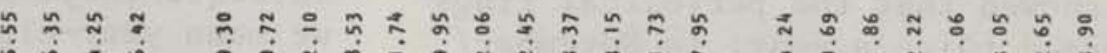

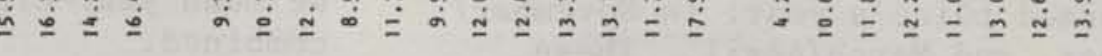

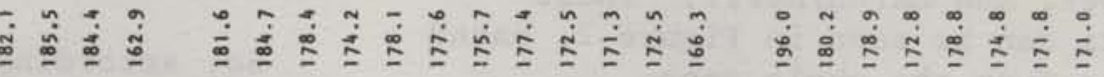

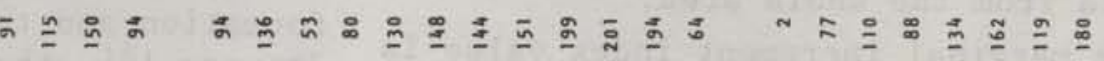

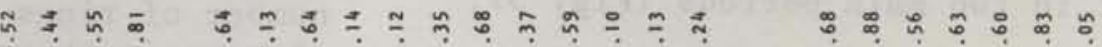

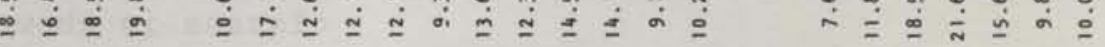

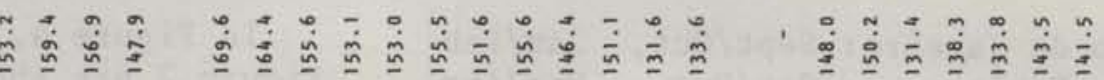

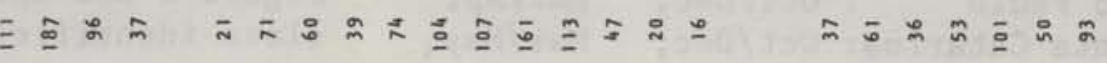

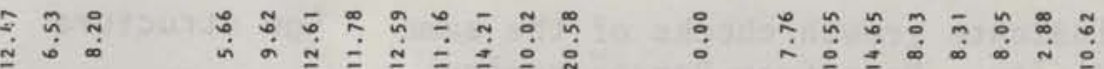

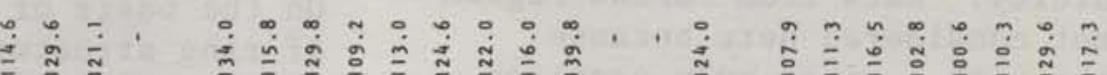

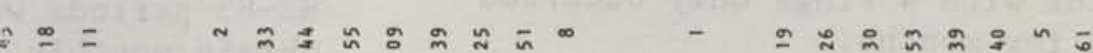

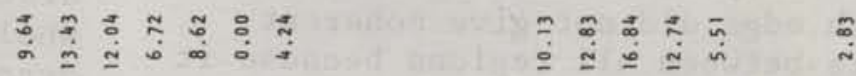

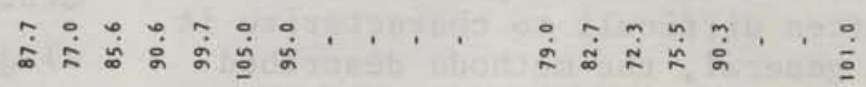

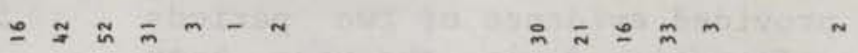

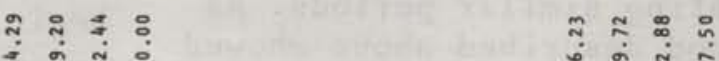

जิ

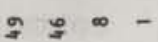
$\simeq 2 n$ ? 


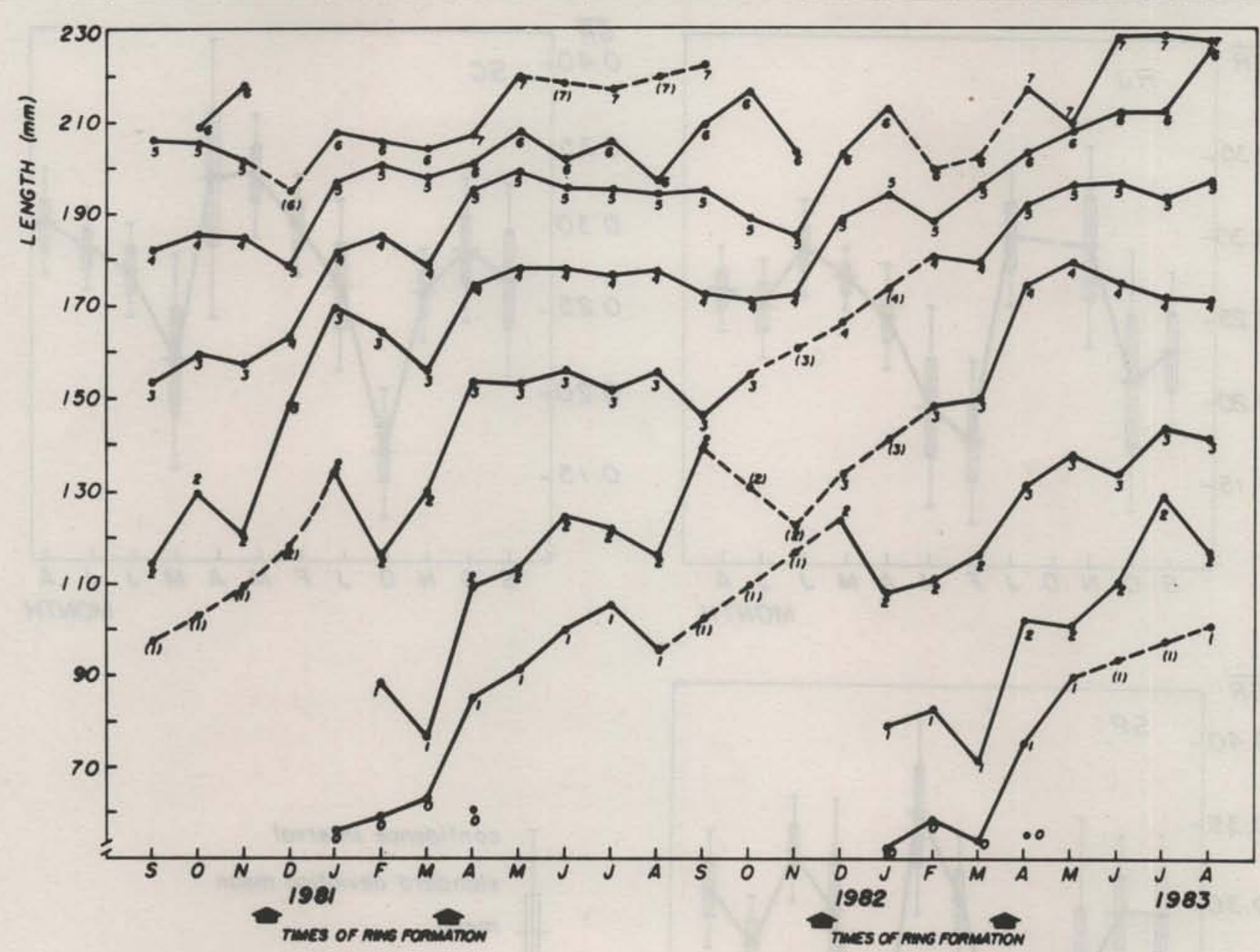

Fig. 2. Sequence of monthly mean length from sardines with the same number of rings on the otoliths, from the whole studied area during September/1981 to August/1983. Times of ring formation area indicated. ()$=$ number of rings for estimated mean, as no data were available.

Table 3. Identification of the number of rings in otoliths to age classes, by month.

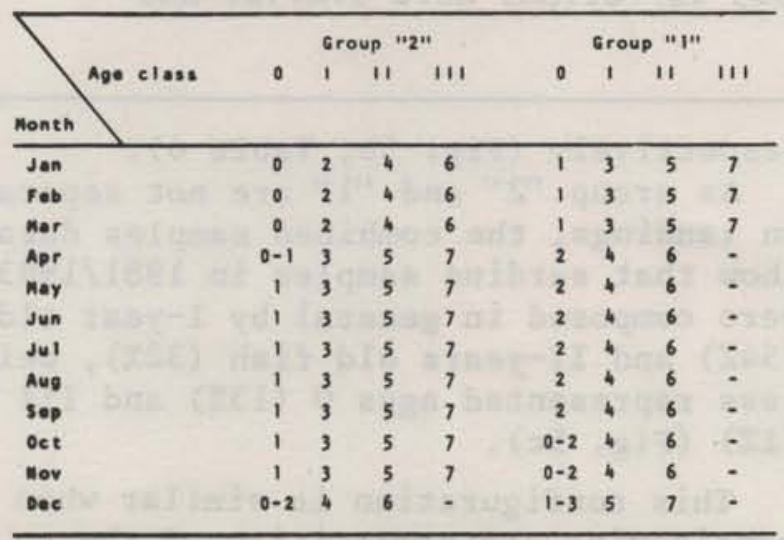

In the fourth year of life (age-III) fish were found measuring 180 to $230 \mathrm{~mm}$ occurring only till August-September. After this period fish belonging to this group did not occurred. It was not found 4-years old fish.

b) Group "1": the oldest fish (Table 5). Fish born earlier within the spawning period begin to appear in the commercial fishery in January with $60 \mathrm{~mm} \mathrm{~L}$. Fish $50 \mathrm{~mm} L_{t}$ have been found in the artisanal fishery in March. These 0 -year old individuals grow during the year reaching up to $180 \mathrm{~mm}$ in December. At age-I they also occur along all the months, since January with $120 \mathrm{~mm}$ long till the end of the year with $230 \mathrm{~mm}$. This group grows to age-II ranging from $160 \mathrm{~mm}$ to $240 \mathrm{~mm}$, occurring at low 

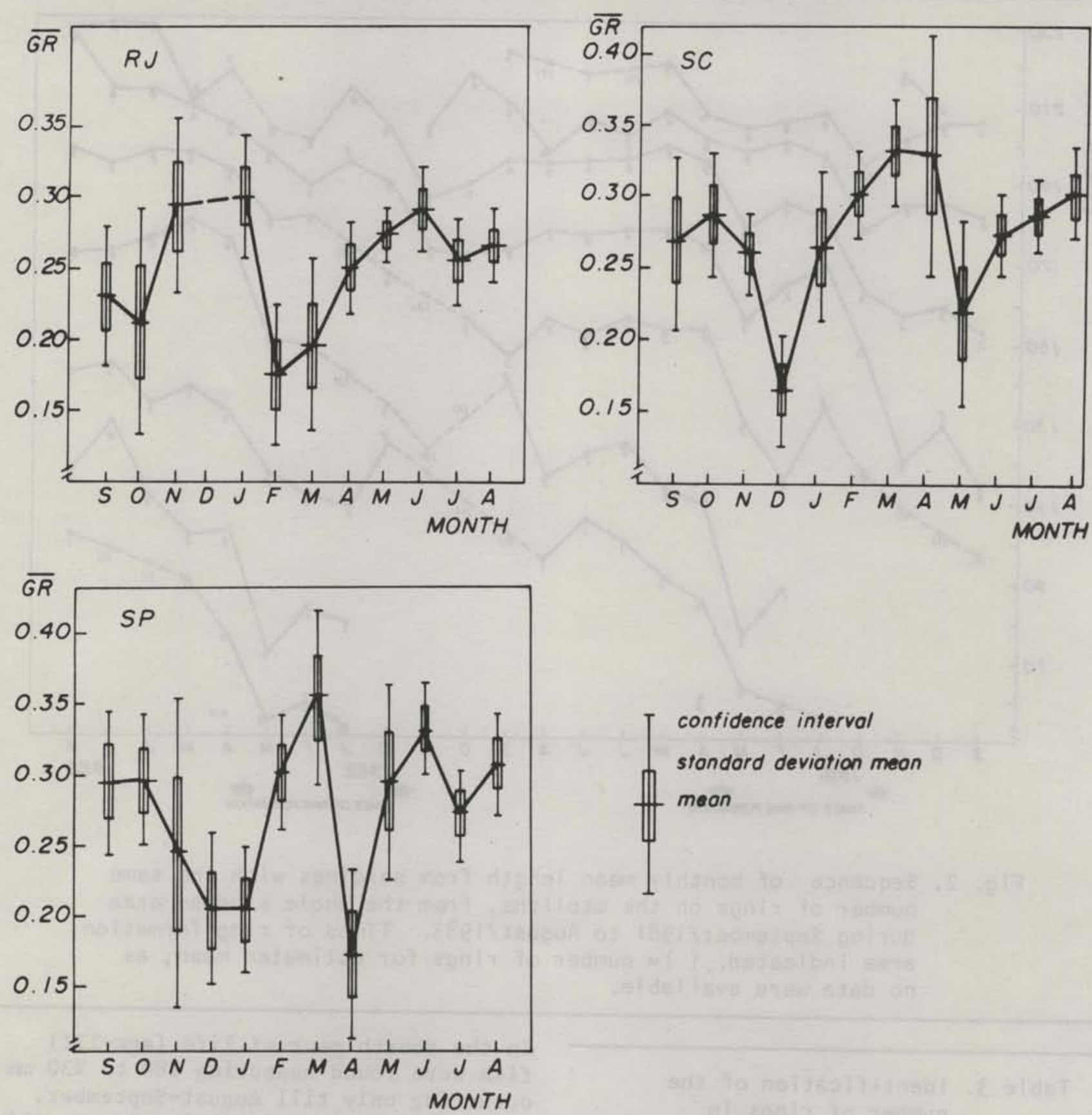

Fig. 3. Marginal increment index variations for sardines from Rio de Janeiro (RJ), São Paulo (SP) and Santa Catarina (SC) regions, during 1981/1982. The 1982/1983 variations were similar and perfectly representative.

numbers in the second semester. Fish III-years old, or older, were not found.

Considering the participation of each age class during the studied period, group "2" samples were composed mainly by fish at age-II ( $51 \%)$; age-I

corresponded to $40 \%$ and the remaining $9 \%$ to ages $0(7 \%)$ and III (2\%) (Fig. $5 \mathrm{a})$. Group " 1 " samples were composed mainly by age I (62\%), being ages 0 and II representated by $18 \%$ and $20 \%$ respectively (Fig. 5b, Table 6).

As group " 2 " and " 1 " are not separated in landings, the combined samples data show that sardine samples in 1981/1983 were composed in general by I-year old $(54 \%)$ and II-years old fish $(32 \%)$, being less represented ages $0(13 \%)$ and III (1\%) (Fig. 5c).

This configuration is similar when considering age composition of the sardine total annual landings, the 


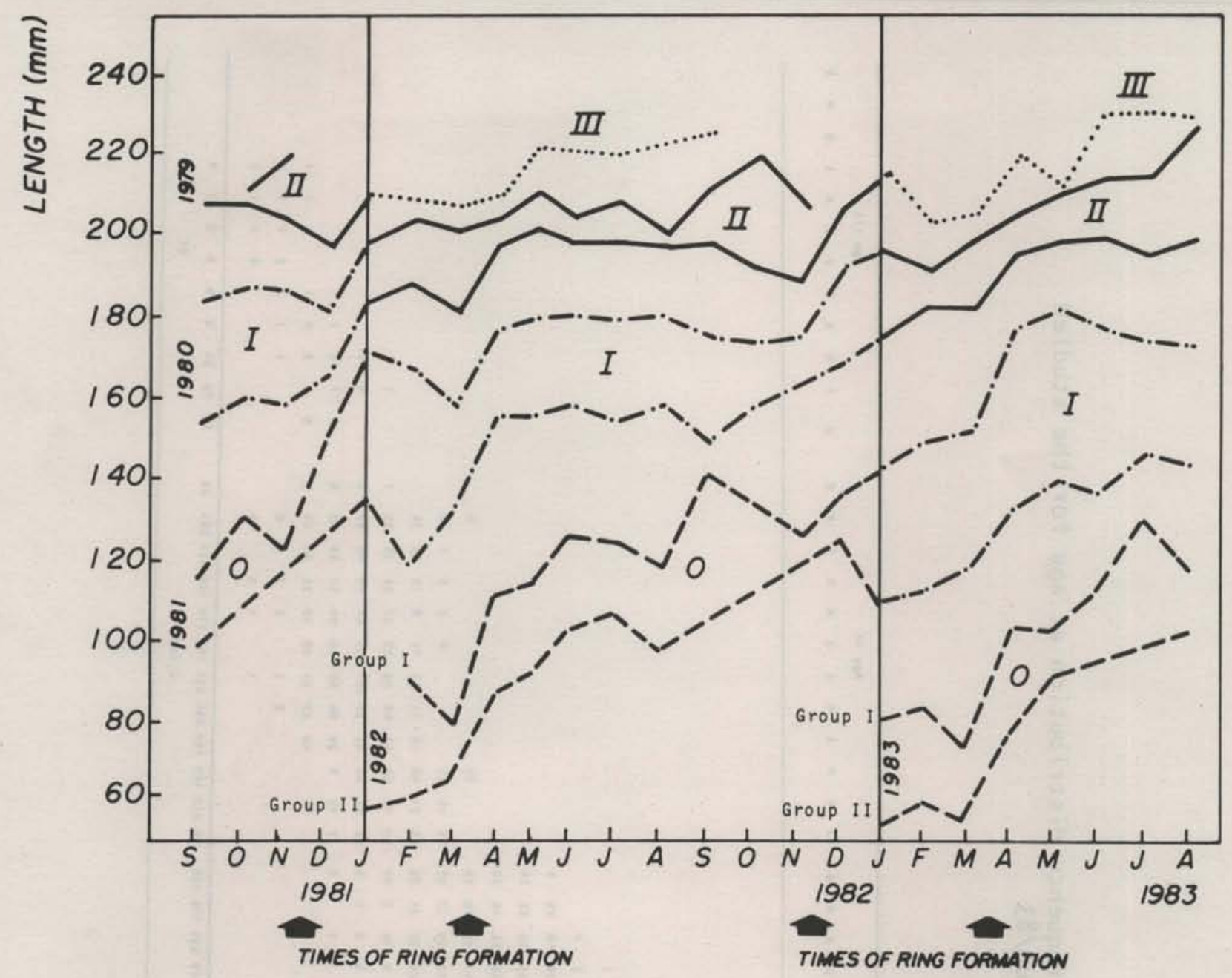

Fig. 4. Same sequences of Figure 2 are shown here according to the age class identification. Each two lines (groups "2" plus IIII) represent a year-class.

proportion of ages I and II being greater than 0 and III; some variations between years may occur (Fig. 6).

However, as smaller than $120 \mathrm{~mm}$ fish generally do not occur in landings, the percentage of age 0 is much lower (1\%) than that in the samples (13\%).

In order to verify any differential growth between sexes, data from 3,407 males and 4,009 females combining two-months periods were analysed (Table 7). The results showed that young fish with defined sex begin to appear in the fishery with $90 \mathrm{~mm} \mathrm{Lt}$ about April. Males and females 0 - and I-year old have equivalent sizes when compared for each two-month period; from the end of age-I on (about 23 months old), females showed greater sizes than that of males by about $5 \mathrm{~mm}$, this difference increasing to about 10 to $20 \mathrm{~mm}$ from middle II-age on. Data showed that female fish attain a greater length than male fish: in the studied period, the largest female fish aged measured $230 \mathrm{~mm}$, and the largest male $214 \mathrm{~mm}$, both III-years old. These differences were not statistically tested, but it seems that growth between males and females is different from sexual maturity on.

\section{Growth parameters}

To follow the sardine growth in sucessive months, mean length values for two-months were obtained, considering the whole area. The data of both groups were pooled for all population, aiming application in analitic models for stock assessment.

As in this study sampling comprised two years, we composed a set of data in 


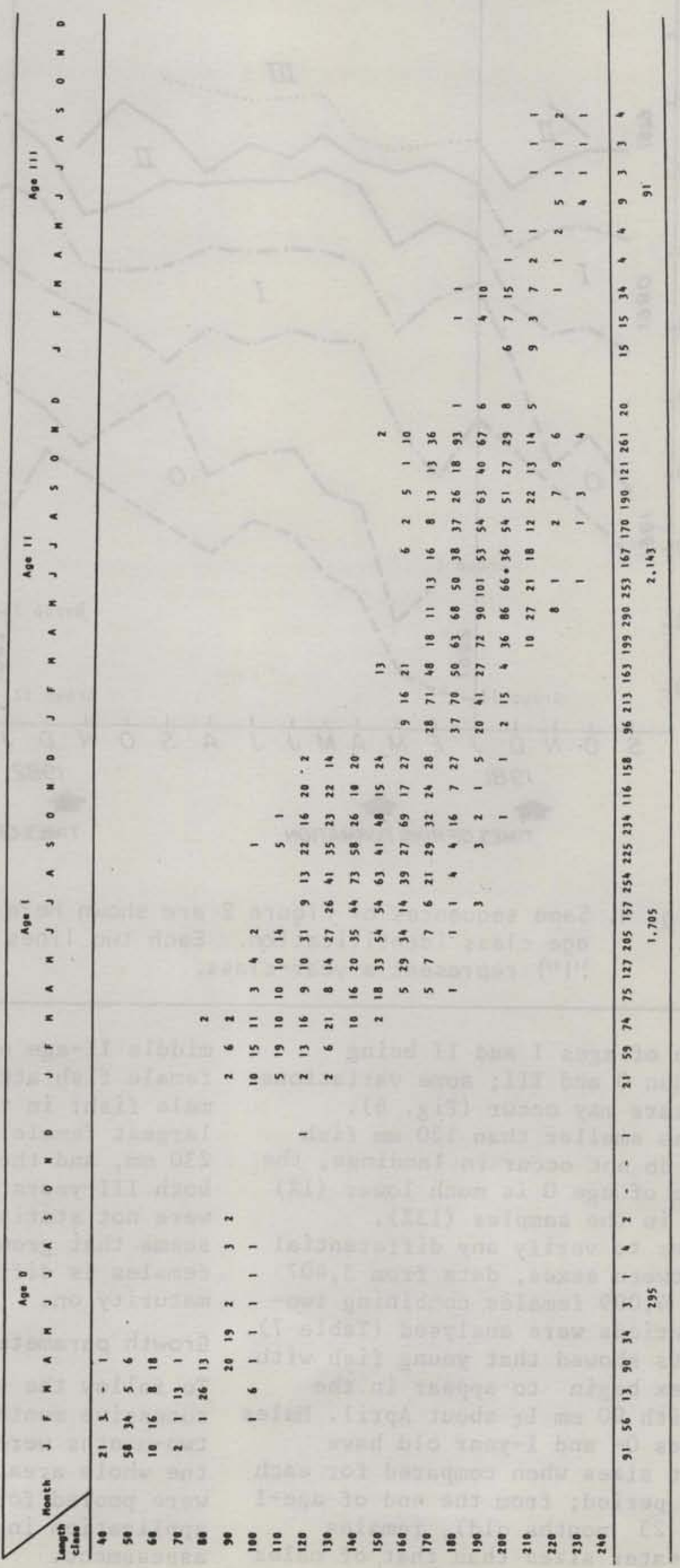




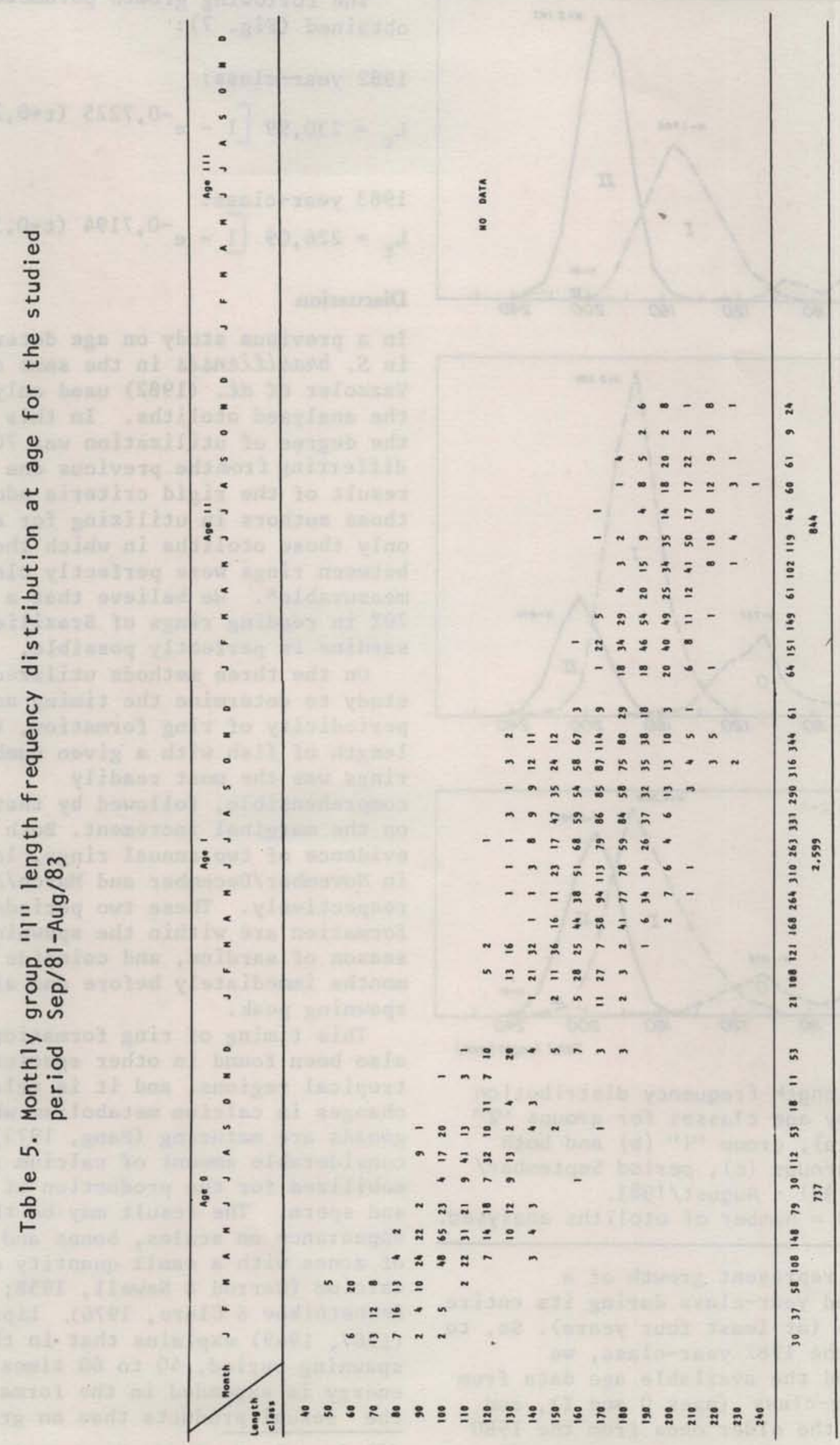



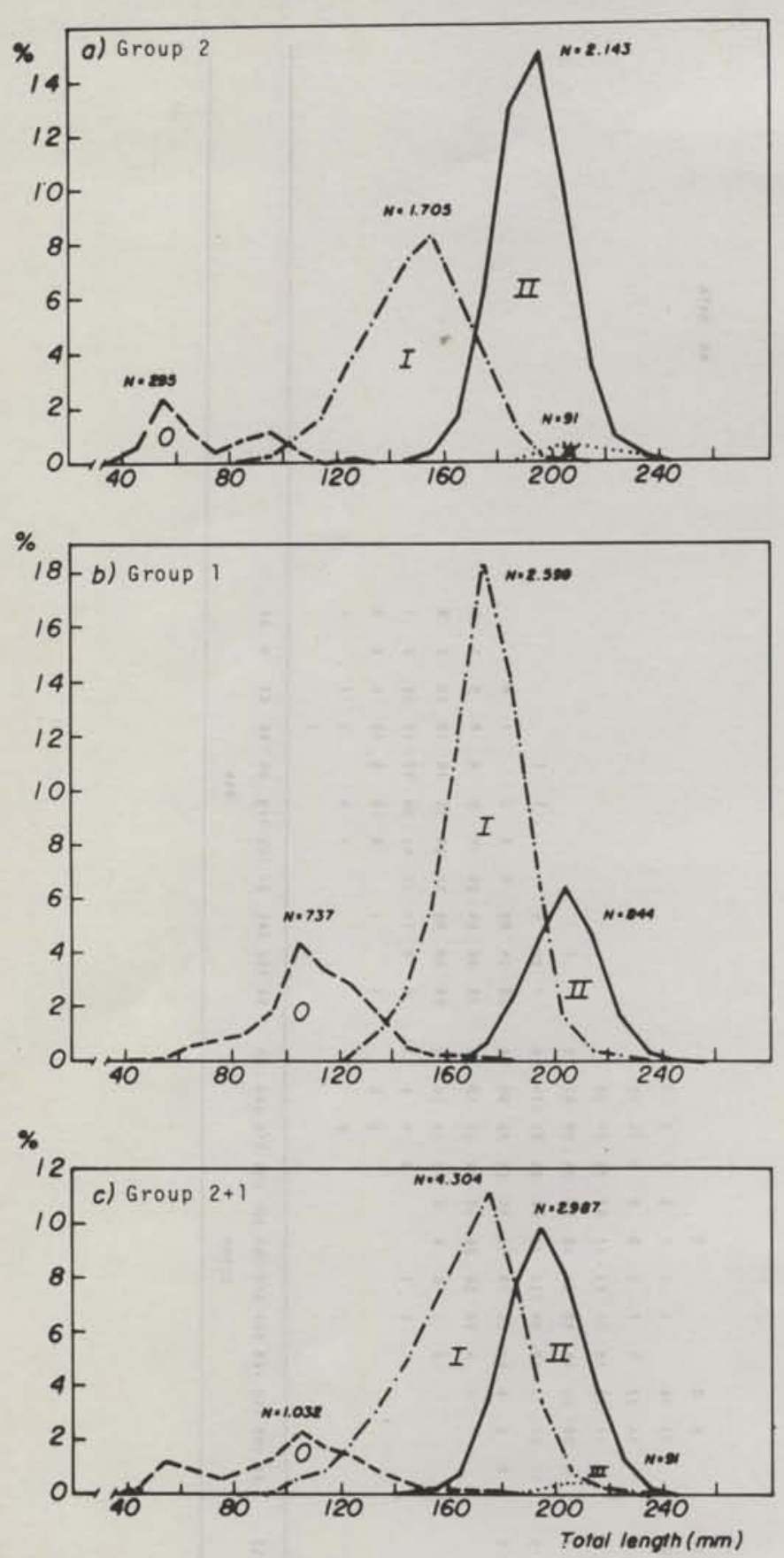

Fig. 5. Length frequency distribution by age classes for groups "2" (a), group "l" (b) and both groups (c), period September/ 1981 - August/1983.

$\mathrm{N}=$ number of otoli ths analysed.

order to represent growth of a

determined year-class during its entire existence (at least four years). So, to compose the 1982 year-class, we considered the available age data from this year-class (ages 0 and $I$ ), and included the older ones from the 1980 year-class. The same procedure was done for the 1983 year-class, complemented with 1981 year-class data.

The following growth parameters were obtained (Fig. 7):

1982 year-class:

$L_{t}=230,99\left[1-e^{-0,7225(t+0,2496)}\right]$

1983 year-class :

$L_{t}=226,09\left[1-e^{-0,7194(t+0,3432)}\right]$

\section{Discussion}

In a previous study on age determination in S. brasiliensis in the same area, Vazzoler et al. (1982) used only $26 \%$ of the analysed otoliths. In this study the degree of utilization was $70 \%$, differring from the previous one as a result of the rigid criteria adopted by those authors in utilizing for analysis only those otoliths in which the gaps between rings were perfectly clear and measurable*. We believe that a value of $70 \%$ in reading rings of Brazilian sardine is perfectly possible.

On the three methods utilized in this study to determine the timing and periodicity of ring formation, the mean length of fish with a given number of rings was the most readily comprehensible, followed by that based on the marginal increment. Both provided evidence of two annual rings, laid down in November/December and March/April respectively. These two periods of ring formation are within the spawning season of sardine, and coincide with months immediately before and after the spawning peak.

This timing of ring formation has also been found in other species of tropical regions, and it is related to changes in calcium metabolism while the gonads are maturing (Pang, 1973); a considerable amount of calcium is mobilized for the production of eggs and sperm. The result may be the appearance on scales, bones and otoliths of $z$ ones with a sam11 quantity of calcium (Garrod \& Newe11, 1958; in Reshetnikov \& Claro, 1976). Lipskaya (1967, 1969) explains that in the spawning period, 40 to 60 times more energy is expended in the formation of the sexual products than on growth,

(*) Dra. A. E. A. de M. Vazzoler, personal communication, 1987. 
Table 6. Annual length frequency distribution at age, for groups " 2 " and "l", for the studied period Sept/81-Aug/83.

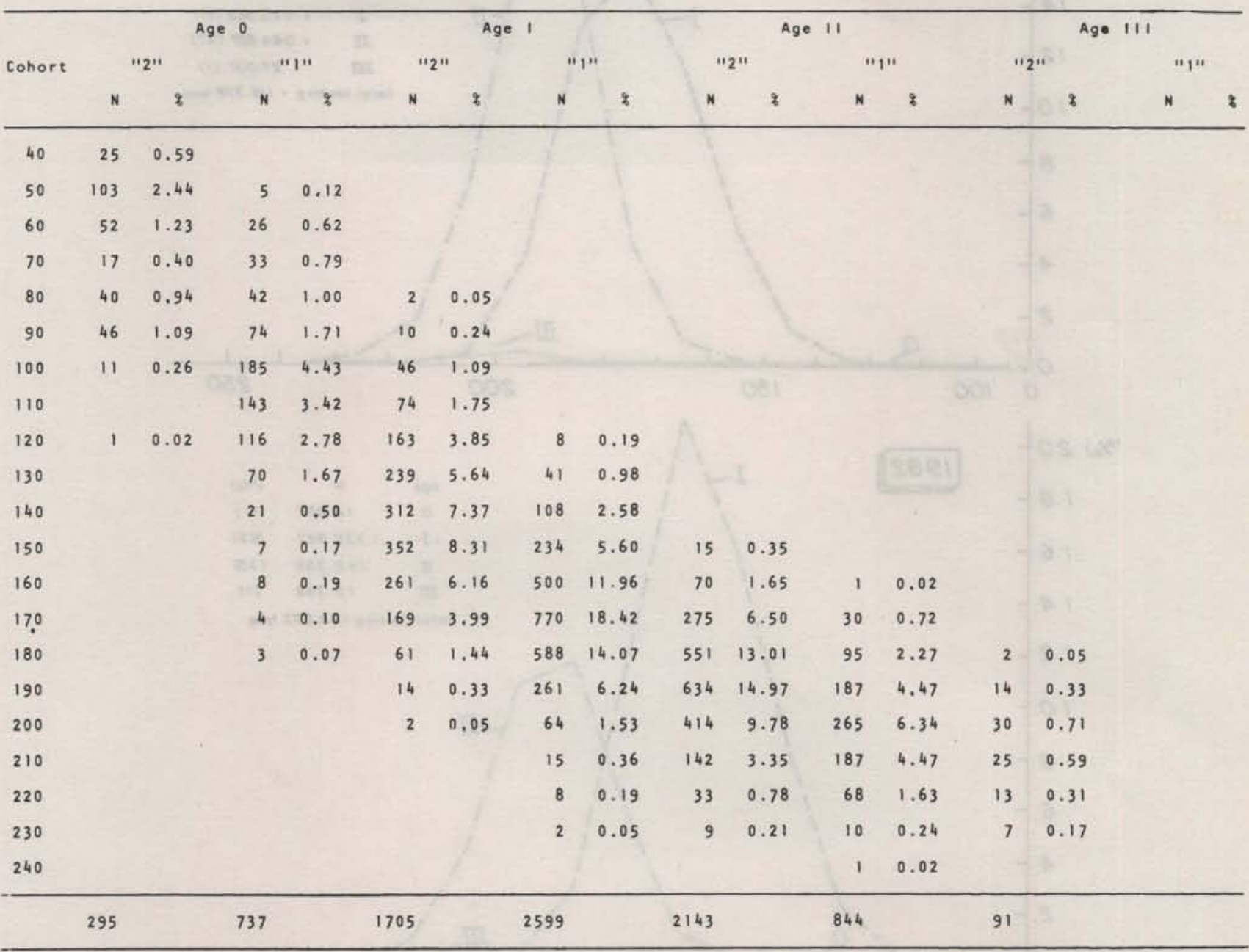

this being reflected in the ring formation. in bony structures of these fish.

For Sardinella aurita, in the Lybian coastal waters, it is apparent that the hyaline zone in otoliths is laid down during the period of gonad maturation and spawning in adult fish (Pawson \& Giama, 1985). On the other hand, the rings in scales of the oil-sardine, $S$. longiceps, in Indian waters may be formed due to poor feeding in summer months (Bensan, 1968). In Sardinops neopilchardus in Australia it may be regarded as a sudden check in growth due to assumption of shoaling habit of the species (in Balan, 1968). In our study it is difficult to state the cause of ring formation; according to Skorniakov (1964), under certain conditions two rings are regularly formed a year in tropical fish with partial spawning and Nekrasov (1979) cites several examples from literature for tropical fish where two rings a year are formed.

For the same genus, Baptista (1977; cit. in Thomas, 1983) found that the Angolan sardinellas (Sardinella aurita and $S$. eba) form two hyaline rings annually. Also in the otoliths of the Southwest African pilchard Sardinops ocellata, it was observed that more than one ring is laid down each year (Thomas, 1984), and in this case, the broad hyaline zone formed between September and December was referred to as the annual ring and considered in the countings. Rings on $S$. brasiliensis'otoliths formed in November/December and March/April could be related to some other factor, not directly associated with reproduction, because they have been observed as much in sexually mature as 

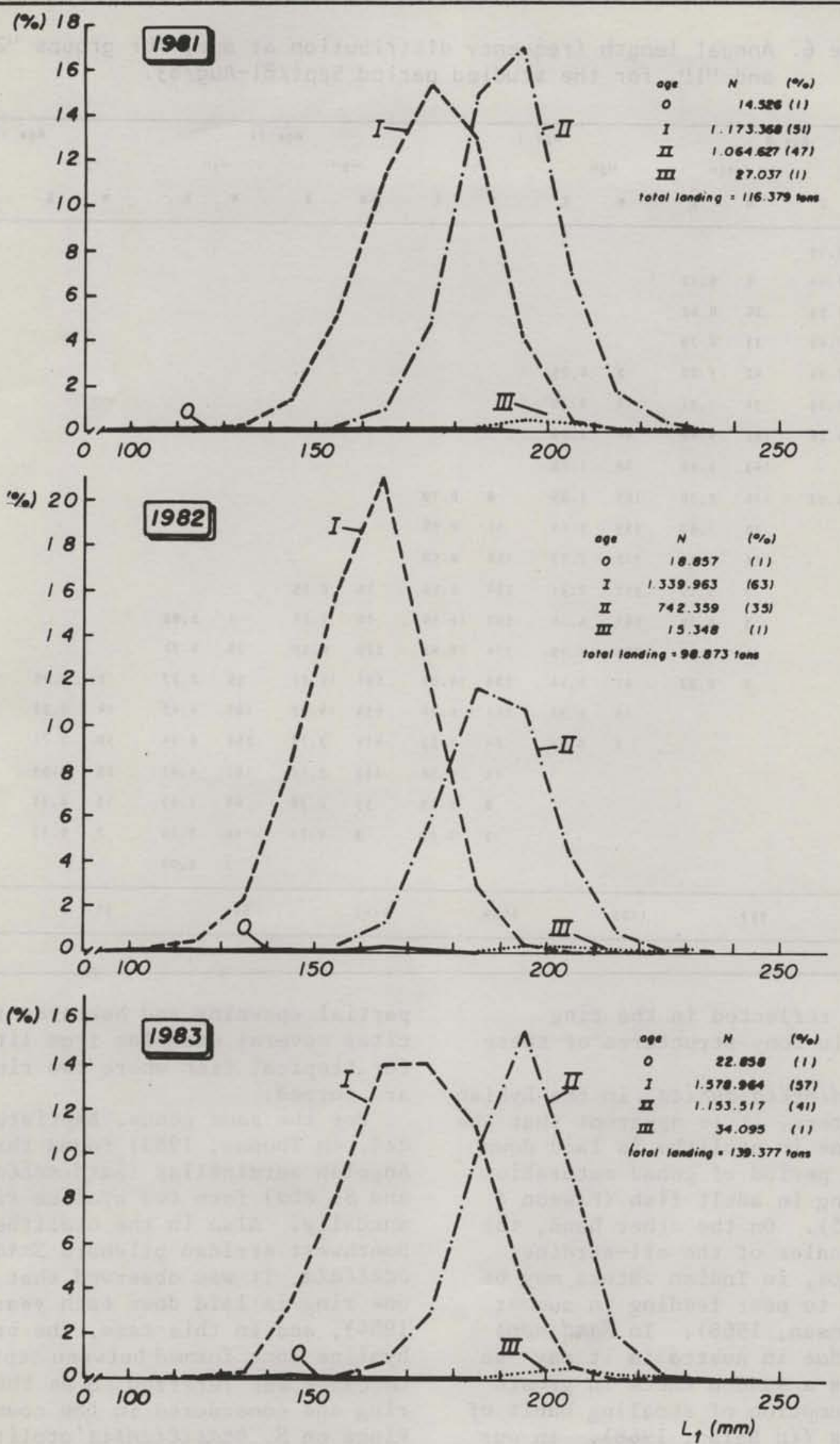

Fig. 6. Length composition of sardines at age as determined by otoliths, from the total landings in 1981, 1982 and 1983 .

$\mathrm{N}=$ number of $\mathrm{fish}$ 
Table 7. Mean length at age by two-month periods, considering males and females separated. Asterisk indicate for each tow months the greatest value between sexes, without statistical comparison

\begin{tabular}{|c|c|c|c|c|c|c|c|c|c|c|c|}
\hline \multirow[b]{2}{*}{ Age } & \multirow[b]{2}{*}{$\begin{array}{l}\text { Number of } \\
\text { rings }\end{array}$} & \multirow[b]{2}{*}{ Sampling } & \multicolumn{2}{|c|}{$\begin{array}{c}\text { Years-class } 1982 \\
\text { Males }\end{array}$} & \multicolumn{2}{|c|}{ Females } & \multirow[b]{2}{*}{ Sampling period } & \multicolumn{2}{|c|}{$\begin{array}{c}\text { rs-Class } 1983 \\
\text { Males }\end{array}$} & \multicolumn{2}{|c|}{ Females } \\
\hline & & & N & $i_{t}$ & N & $i_{t}$ & & N & $i_{t}$ & N & $i_{t}$ \\
\hline \multirow{6}{*}{0} & $0-1$ & Jan-Feb/82 & - & - & - & - & $\mathrm{Jan}-\mathrm{Feb} / 83$ & - & - & - & - \\
\hline & $0-1-2$ & Mar-Apr & 2 & 124.00 & 3 & 126.00 & Mar-Apr & 7 & 110.00 & 10 & 101.10 \\
\hline & $1-2$ & May-Jun & 34 & 126.12 & 29 & 119.07 & May-Jun & 26 & 106.35 & 36 & 106.53 \\
\hline & $1-2$ & Jul-Aug & 7 & 128.00 & 12 & 131.83 & JuI-Aug & 31 & 118.84 & 30 & 117.73 \\
\hline & $1-2$ & Sep-oct & 3 & 136.00 & 3 & 148.00 & Sep-0ct/81 & 16 & 111.19 & 21 & 122.38 \\
\hline & $1-2-3$ & Nov-Dec & 8 & 136.75 & 5 & 133.00 & Nov-Dec & 25 & 140.56 & 20 & 145.80 \\
\hline \multirow{6}{*}{1} & $2-3$ & $\mathrm{Jan}-\mathrm{Feb} / 83$ & 25 & 143.96 & 19 & 144.37 & Jan-Feb/82 & 49 & 171.26 & 31 & 168.81 \\
\hline & $2-3-4$ & Mar-Apr & 63 & 161.16 & 105 & 158.52 & Mar-Apr & 61 & 166.18 & 94 & 163.55 \\
\hline & $3-4$ & May-Jun & 226 & 164.93 & 209 & 162.41 & May-Jun & 201 & 168.03 & 248 & 169.41 \\
\hline & $3-4$ & Jul-Aug & 193 & 160.54 & 240 & 163.64 & Jul-Aug & 248 & 167.16 & 298 & 165.97 \\
\hline & $3-4$ & Sep-0ct/81 & 222 & 170.03 & 268 & 168,48 & Sep-0ct & 270 & 165.63 & 274 & 165.76 \\
\hline & $3-4-5$ & Nov-Dec & 154 & 169.77 & 192 & 172.72 & Nov-Dec & 183 & 170.16 & 145 & 173.34 \\
\hline \multirow{8}{*}{ II } & $4-5$ & Jan-Fev/82 & 162 & 183.26 & 173 & 192.89 & $\mathrm{Jan}-\mathrm{FeV} / 83$ & 84 & 181.64 & 104 & 188.58 \\
\hline & $4-5-6$ & Mar-Apr & 88 & 188.50 & 95 & 195.94 & Mar-Apr & 183 & 187.81 & 202 & 192.31 \\
\hline & $5-6$ & May-Jun & 82 & 195.90 & 118 & 201.39 & May-Jun & 241 & 196.52 & 320 & 204.28 \\
\hline & $5-6$ & Jul-Aug & 55 & 192.36 & 65 & 197.95 & Jul-Aug & 139 & 196.89 & 182 & 202.81 \\
\hline & $5-6$ & Sep-oct & 112 & 194.40 & 163 & 199.24 & Sep-0ct/81 & 59 & 203.34 & 46 & 209.09 \\
\hline & $5-6-7$ & Nov-Dec & 85 & 184.46 & 127 & 190.24 & Nov-Dec & 33 & 202.76 & 60 & 203.73 \\
\hline & $6-7$ & Jan-Fev/83 & 8 & 202.62 & 10 & $208.70^{\circ}$ & Jan-Fev/82 & 2 & 204.00 & 10 & 207.40 \\
\hline & $6-7$ & Mar-Apr & 3 & 212.33 & 7 & 204.14 & Mar-Apr & 13 & 202.69 & 16 & 203.81 \\
\hline \multirow[t]{3}{*}{111} & 7 & May-Jun & 1 & 209.00 & 9 & 228.00 & May-Jun & 1 & 213.00 & 2 & 223.00 \\
\hline & 7 & Jul-Aug & 1 & 214.00 & 4 & 230.25 & Jul-Aug & - & - & 1 & 217.00 \\
\hline & $20+15$ & Sep-Oct & - & - & - & - & Sep-0ct & 1 & 214.00 & 3 & 225.67 \\
\hline
\end{tabular}

in immature individuals. It is assumed that in adults the same factor can trigger ring formation in the periods considered here. In the literature there are instances where the formation of hyaline zones in the otoliths of sexually immature animals is caused by an inherent rhythm linked with the reproductive cycle - e.g. the European hake (Hickling, 1935), pilchard (Davies, 1956; Baird, 1970) and the Cape hakes (Botha, 1971). Whatever may be the cause for the checks in $S$. brasiliensis otoliths, they seem to be periodic and so they can be used to indicate the age in this species.

While ageing the otoliths in the present work, a11 we11-formed rings were counted without any attempt to discriminate between those referring to growth or other causes. This procedure was adopted taking into account the possibility that any person might be involved in performing the counts. Considering the results, this method proved to be efficient: Vazzoler et al. (1982), found the same number of rings in the otoliths of Brazilian sardine (up to 7 rings), and in both their study and ours, the mean length of fish with a 


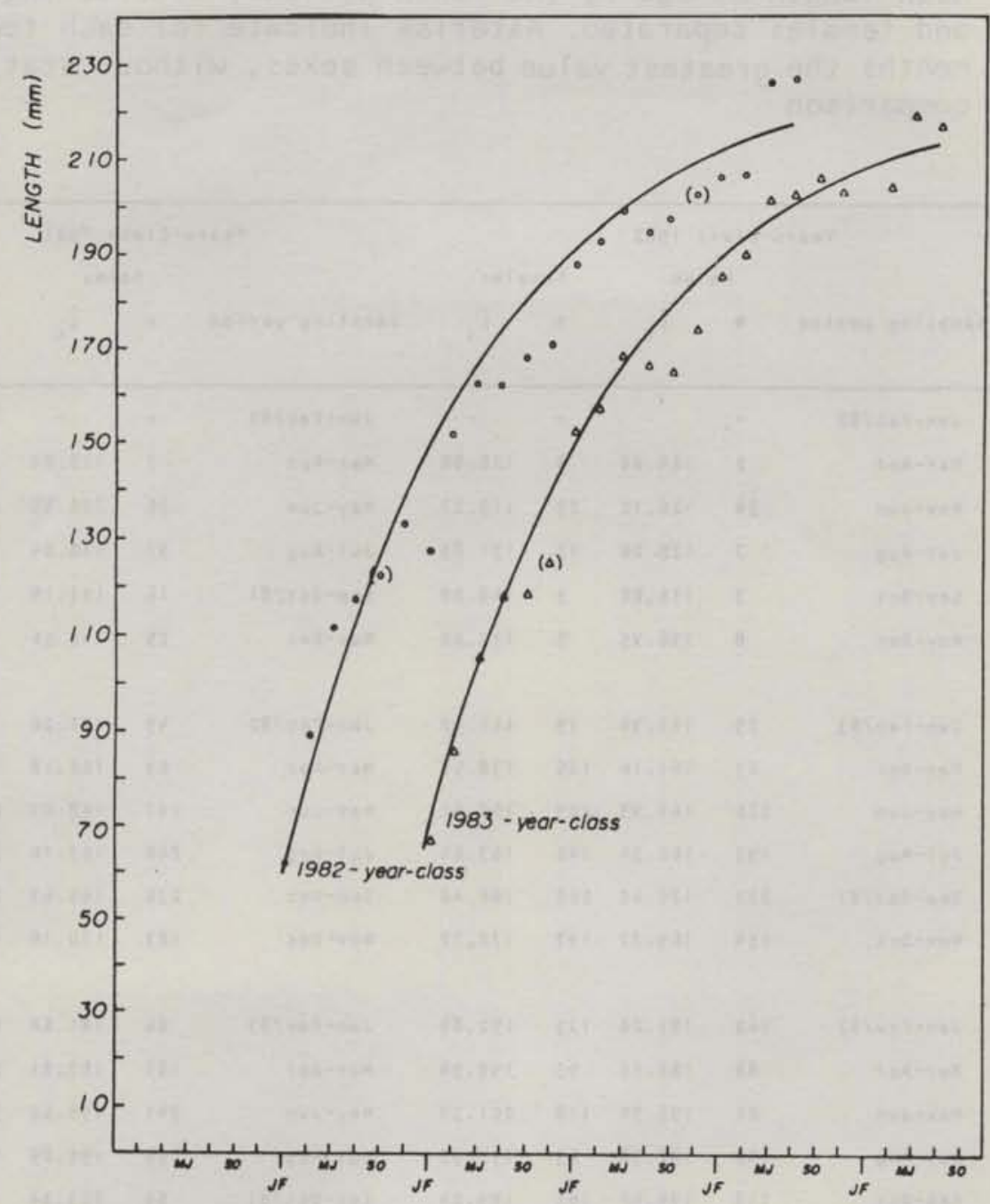

Fig. 7. Growth curves for 1982 and MONTH 1983 year-classes. Groups "I" and "2" combined.

( ) Estimated values.

given number of rings are similar, which indicates that the readings were comparable. The present interpretation differs from that of Vazzoler et al. (1982) in relation to the attribution of age, since they considered that only one ring is formed annually, finding that age ranges from 0 to 7 -years old whereas we consider the age to range from 0 to 3 -years old in $S$. brasiliensis. However, the authors cited above analysing the monthly variation of otoliths with hyaline and opaque edges, found a peak in hyaline zone formation also in April (fig. 6 from page 80 ), which they attributed to spawning, without taking it into account for age determination. Richardson et al. (1960) also found up to 7 rings in scales of $S$. brasiliensis from Santos and Rio de Janeiro, and suggested the Brazilian summer as the period of ring formation. It is interesting to note that they supposed an annual rings formation on scales, but mentioned that certain anomalies could not be explained. The period when length at age is at a minimum, according to Richardson et al., lop. cit.) corresponds to that of

November/December, when we also verified a miniumum length per ring in summer. After an increase in mean length values per ring, we find a second low value, verified in summer (March/Apri1).

The wide range of lengths found for each age class, mainly for ages 0 and $I$, is easily explained by the length of the spawning period of Brazilian sardine. When groups " 1 " and 
"2" are graphically separated, there is a small overlap of length within age classes (Fig. 5a,b). It should also be noted that both ages II and III show a wide overlap, suggesting that at these ages the species is approaching its maximum size. In fact, according to Pauly's equation (Pauly, 1980) in which maximum longevity of fish can be expressed by $t_{\max }=3 / K+t_{0}$, we found a maximum age of 3,9 and 3,8 for S. brasiliensis in 1982 and 1983, respectively. These values are approximate to that found by Matsuura (1983), who found 4,3 and it should be noted that in that work only fish from the northern part of the distributional area - therefore larger fish-were considered for study.

The occurrence of few individuals of age III and older in the catches provides evidence of the short life span of the Brazilian sardine.

The data obtained during this study through ageing of otoliths showed that sardine fishery is practically based upon ages I (54\%) and II (32\%) individuals, and it is interesting to note that the same results were obtained through the analysis of length composition of catches from 1974 to 1980 in the same area (PDP/SUDEPE, 1985).

We find in literature several examples in which the average size of sardine females is greater than that of males by a few millimeters Phillips, 1948; Ben-Tuvia, 1960; Pawson-Giama, 1985. As occurs with S. brasiliensis the difference is relatively small in young fish, but it increase as the fish become older.

According to Matsuura (1983), Brazilian sardine reaches sexual maturity at the end of age 0 at a total length of $160 \mathrm{~mm}$. Our samples showed that no fish from group "2" was ripe or spent at the end of age 0 ; we presume that these fish do not spawn in the summer of the year after the fish are born, first spawning occurring only in the summer of their second year of life (at the end of age-I or starting age-II). In relation to group " 1 " $\mathrm{fish}$, ripe and spent individuals from the year-class 1981 (spawning season 80/81) were found in December/81 (age-0) and February/82 (age-I); those from the year-class 1982 (spawning season $81 / 82$ ) were found spawning only in March/83 (age-I) (Table 6). These results show clearly that fish may spawn for the first time in the summer of the year after they are born, when they are the oldest (largest) from a given year-class and able to attain length at first maturity in this period, that is 160-170 mm total length (Rossi-Wongtschowski, 1977). Considering that Matsuura's work (1983) was based upon fish sampled from the Rio de Janeiro region - where spawning generally occurs earlier than in southern regions of its distributional area (Saccardo \& Isaac-Nahum, 1983), it is possible to find sexually mature $f i s h$ at age- 0 , but our results suggest that this does not occur for the whole population.

For the closely related species Sardinella anchovia, Prosvirov \& Varea (1965) believed that this sardine in the northeastern Gulf of Mexico reached sexual maturity during its second year at a length of 140-150 mm standard length. In Venezuela, S. anchovia was found to be sexually mature between the ages of II and III years at a total length of $195 \mathrm{~mm}$ (Simpson \& Gonzalez, 1967).

For the Indian oil-sardine, Sardinella longiceps, those born in July-August have a faster growth rate than later recruits (Anthony Raja, 1970). Similar observation is possible to be made for $S$. brasiliensis in this study, if growth parameters for group "2" and "1" are separately obtained: group " 1 " present higher growth rate than group "2". This may be related to the warm period to which they are submitted, as group " 1 " $\mathrm{fish}$ are born at the beginning of the summer season, growing faster than group "2" fish.

Growth parameters values of S. brasiliensis, considering together data from both group, are coherent with data found in literature for the genus in other areas (Pauly, 1978). Values for $K$ are about 0.7, $\mathrm{L}_{\infty}$ about $230 \mathrm{~mm}$ and $t_{0}$ ranges from $-0,23$ to $-0,34$. For the most relative species $S$. anchovia from Venezuela, values of $K$ and $L_{\infty}$ are 0,7 and $240 \mathrm{~mm}$, 
respectively (Heald \& Griffiths, 1967; Simpson, 1971).

Other authors have obtained similar values to ours for Brazilian sardine:

Santos \& Fratzen (1965)

$$
\left[L_{t}=24.31-e^{-0.50 t}\right]
$$

Matsuura (1977)

$$
\left[L_{t}=24.41-e^{-0.44 t}\right]
$$

Matsuura (1983)

$$
\left[L_{t}=26.01-e^{-0.62(t+0.588)}\right]
$$

PDP/SUDEPE (1985)

$$
\left[L_{t}=24.01-e^{-0.62(t+0.588)}\right]
$$

However, those studies did not include fish from the whole area of abundance of this species, and/or presuposed that $t_{0}=0$.

In conclusion, this work shows a different way of interpreting age of $S$. brasiliensis through otoliths rings. Having found two rings formed a year, the age varies from 0 to III years along the occurrence area of the species.

The cause of ring formation may be linked to the reproductive cycle. As cited above, there are evidences that the pre-spawning stages are attained in fish from the Rio de Janeiro samples in November, and later in those from São Paulo and Santa Catarina regions. This indicates that the spawning process begins earlier in the northern region

(Saccardo \& Isaac-Nahum, 1983).

The marginal increment index values shown in this work also suggest a progressive north-south shift in time (Fig. 3). This fact may be related to the previous observation, inforcing the argument of the cause of ring formation.

\section{Resumo}

A idade da sardinha Sardinella brasiliensis foi determinada pelo exame de otólitos de exemplares provenien- tes de desembarques da pesca comercial e artesanal, na ārea compreendida entre $22^{\circ} \mathrm{S}$ (Cabo Frio, RJ) e $28^{\circ} \mathrm{S}$

(Cabo de Santa Marta, Grande, SC), durante o período 1981-83. Este estudo é parte de um programa mais amplo denominado "Programa Integrado de Estudos Biológicos sobre Sardinha", desenvolvido na região sudeste do Brasil desde 1981, objetivando conhecer as variações dos parâmetros biológicos da espécie, e fornecer subsídios à avaliação pesqueira do recurso.

Foram contados os anéis translücidos dos otólitos, colocados inteiros em recipientes de fundo preto, imersos em álcool $70 \%$ e iluminados com luz incidente sob estereomicroscópio binocular. Além das contagens, foram efetuadas medidas das distâncias do núcleo do otólito ao bordo, e do núcleo a cada anel translúcido, bem como observações da natureza do bordo. Foram utilizados três métodos para determinar a época e periodicidade de formação dos anéis. Os parâmetros de crescimento $L_{\infty}$, $K$ e $t_{0}$ foram estimados, e as curvas ajustadas usando-se a equação de von Bertalanffy. Os resultados mostraram que os otólitos possuem de 0 a 7 anéis, sendo formados dois anéis por ano: um entre novembro-dezembro, e outro entre março-abril. Estas épocas estão intimamente ligadas ao período de reprodução. Descreveu-se um método para a determinação da idade de sardinha, tendo sido identificadas classes etárias de 0 a 3 anos. Verificou-se também a ocorrência de dois grupos de peixes dentro de um dado período de desova (outubro e março), que representariam individuos que nascem no início da estação de desova, e aqueles que nascem posteriormente; ambos grupos formam uma classe anual. Os parâmetros de crescimento obtidos foram:

classe anual 1982:

$$
L_{t}=230,99\left[1-e^{-0,7225(t+0,2496)}\right]
$$

classe anual 1983:

$$
L_{t}=226,09\left[1-e^{-0,7194(t+0,3432)}\right]
$$




\section{Acknowledgements}

We thank all scientists from the Integrated Programme of Biological Studies on Sardine (PIEBS), namely: Dr. H. Valentini; G. S. Melo; S. Jablonski; M. Teixeira-Wenze1; L. G. Domit; R. de D. Cardoso; J. Sá Revoredo; L. Frosch and M. Munhoz.

We also thank Dr. Roger Bailey and Dr. Richard Parrish for reviewing the manuscript and giving their with many valious suggestions.

\section{References}

ANTONY RAJA, B. T. 1970. Estimation of age and growth of the Indian oil-sardine, Sardinella lingiceps Va1. Indian J. Fish., 17(1/2):26-42.

BAIRD, D. 1970. Age and growth of the South African pilchard, Sardinops ocellata. Investl Rep., Div. Sea Fish. S. Afr., (91):1-16.

BALAN, V. 1968. Studies on age and growth of the oil-sardine Sardinella longiceps $\mathrm{Val}$. by mean of scales. Indian J. Fish., $11(2-\mathrm{A})$ :663-686.

BENSAN, P. 1968. Growth variations in the Indian oil-sardine, Sardinella longiceps Valenciennes. Indian $\mathrm{J}$. Fish., $11(2-\mathrm{A}): 699-708$.

BEN-TUVIA, A. 1960. Synopsis of biological data on Sardinella aurita of the Mediterranean Sea and other waters. FAO Fish. Biol. Synopses, (14) : 287-312.

BOTHA, L. 1971. Growth and otolith morphology of the Cape hakes Merluccius capensis (Cast.) and $M$. paradoxus (Franca). Invest1 Rep., Div. Sea Fish. S. Afr., (97):1-32.

CADWALLADER, P. L. 1978. Age, growth and condition of the common river galaxias, Galaxias vulgaris Stoke11, in the Glentui River, Canterbury, New Zealand. Fish. Res. Bull., N.Z., (17) : 9-35.

DAVIES, D. H. 1956. The South African pilchard (Sardinops ocellata). Sexual maturity and reproduction, 1950-1954. Invest1 Rep., Div. Sea Fish. S. Afr., (22) : 1-55.
HEALD, E. J. \& GRIFFITHS, R. C. 1967. La determinación, por medio de la lectura de escamas, de $1 \mathrm{a}$ edad de $1 \mathrm{a}$ sardina, Sardinella anchovia, del Golfo de Cariaco, Venezuela Oriental. Ser. Rec. Explot. pesq., 1(10):375421.

HICKLING, C. F. 1935. Seasonal changes in the ovary of the immature hake (Merluccius merluccius). J. mar. biol. Ass. U.K., 20(2):443-461.

ILES, T. D. \& JOHNSON, P. O. 1962. The correlation table analysis of a sprat (Clupea sprattus L.) year class to separate two groups differing in growth characteristics. J. Cons. int. Explor. Mer., 27(3):287-303.

ISAAC-NAHUM, V. J.; CARDOSO, R. de D.; SERVO, G.; ROSSI-WONGTSCHOWSKI, C. L. D. B. \& TEIXEIRA, M. S. M. 1988. Aspects of the spawning biology of the Brazilian sardine, Sardinella brasiliensis (Steindachner, 1879), (Clupeidae). J. Fish Biol., 32(3): 383-396.

LIPSKAYA, N. Ya. 1967. Assessment of energy expenditure on the manufacture of sexual products in fishes. Cit. in: Nekrasov, V. V., 1979. Hydrobiol. J., $15(2): 35-39$.

1969. Some data on the growth and feeding on the round scad (Decapterus punctatus Agassiz) in the Gulf of Guinea. Cit. in: Nekrasov, V. V., 1979. Hydrobiol. J., $15(2): 35-39$.

MATSUURA, Y. 1977. O ciclo de vida da sardinha-verdadeira (Introdução à Oceanografia pesqueira). Publção esp. Inst. oceanogr., S Paulo, (4):1-146.

1983. Estudo comparativo das fases iniciais do ciclo de vida da sardinha-verdadeira, Sardinella brasiliensis, e da sardinha-cascuda, Harengula jaguana, (Pisces: Clupeidae) e nota sobre a dinâmica da população da sardinha-verdadeira na região sudeste do Brasil. Tese de livre-docência. Universidade de São Paulo, Instituto Oceanográfico. 150 p. + anexos. 
NEKRASOV, B. V. 1979. The causes of annulus formation in tropical fishes. Hydrobio1. J., 15(2):35-39.

PANG, P. K. T. 1973. Endocrine control of calcium metabolism in teleosts. Am. Zoo1., 13(3):775-792.

PAULY, D. 1978. A preliminary compilation of fish length growth parameters. Ber. Inst. Meeresk. Christian-Albrechts-Univ., (55) 1-200.

1980. A selection of simple methods for the assessment of tropical fish stocks. FAO Fish. Circ., (729) :1-54.

PAWSON, M. G. \& GIAMA, M. S. 1985. A biological sampling problem illustrated by the population structure and growth patterns of Sardinella aurita at Tripoli, Lybia. Environ. Bio1. Fishes, 12(2):143-154.

PDP/SUDEPE. 1985. Relatório da Segunda Reunião do Grupo de Trabalho e Treinamento (GTT) sobre Avaliação de Estoques, realizada em Tamandaré/PE, 29 de junho a 24 de julho, 1981. Grupo de Trabalho sobre sardinha. PDP/Sér. Doc. téc., (34):63-108.

PHILLIPS, J. B. 1948. Growth of the sardine, Sardinops caerulea, 1941-42 through 1946-47. Fish Bul1., Calif., (71) $: 1-33$.

PROSVIROV, E. S. \& VAREA, A. 1965. Sardinella anchovia Valenciennes of the Gulf of Mexico. In: Bogdanov, A. S., ed. Soviet-Cuban fishery research. Translated from Russian. Jerusalem, Israel Program for Scientific Translations, 1969. p.247-281.

RESHETNIKOV, Y. S. \& CLARO, R. M. 1976. Time of formation of the annual ring in the Lutjanidae. Hydrobiol. J., $12(3): 30-35$.

RICHARDSON, I. D.; VAZZOLER, G.; FARIA, A. de \& MORAES, M. N. de. 1960. Report on sardine investigations in Brazil. In: Rosa Jr., H. \& Murphy, G., eds Proceedings of the World Scientific Meeting on the Biology of Sardines and Related Species. Roma, FAO Proc. Sardine Meeting, 3(13): 1051-1079.
RIJAVEC, L. \& AMARAL, J. C. 1977. Distribuição e abundância de peixes pelágicos na costa sul e sudeste do Brasil (resultados da pesquisa com ecointegrador). $\mathrm{PDP} / \mathrm{T}$, (24) :55p.

S. C. B.; RODRIGUES, L. F. \& PIRES, M. R. Q. 1977. Contribuição ao conhecimento da biologia e dinâmica da sardinha (Sardinella brasiliensis) em águas brasileiras (resultados preliminares. PDP/SUDEPE, Sér. Doc. Oc., (24):36 p.

ROSSI-WONGTSCHOWSKI, C. L. D. B. 1977. Estudo das variações da relação peso total/comprimento total em função do ciclo reprodutivo e comportamento de Sardinella brasiliensis (Steindachner, 1879) da costa do Brasil entre $23^{\circ} \mathrm{s}$ e $28^{\circ} \mathrm{S}$. Bolm Inst. oceanogr., S Paulo, 26:131-180.

LER, A. E. A. de M. \& BRAGA, F. M. de S. 1982. Estudos sobre estrutura, ciclo de vida e comportamento de Sardinella brasiliensis (Steindachner, 1879), na ärea entre $22^{\circ} \mathrm{S}$ e $28^{\circ} \mathrm{S}$, Brasil. 1. Morfologia dos otólitos. Bolm Inst. oceanogr., S Paulo, $31(2): 57-76$.

SACCARDO, S. A. \& ISAAC-NAHUM, V. J. 1983. Biologia e disponibilidade de sardinha (Sardinella brasiliensis, Steindachner, 1879) na costa sudeste do Brasil. PDP/Doc. téc., (33):265294.

SANTOS, E. P. \& FRANTZEN, F. M. 1965. Growth of sardines: quantitative aspects. Anais Acad. bras. ciênc. 37 (supl.) : 360-262.

SIMPSON, J. G. 1971. The present status of exploitation and investigation of the clupeoid resources of Venezuela. Fish. Rep. FAO no 71-2:263-278. Caribbean Symposium. 
SIMPSON, J. G. \& GONZALEZ G., G. 1967. Some aspects of the early life history and environment of the sardine, Sardinella anchovia, in eastern Venezuela. Ser. Recur. Explot. pesq., Minist. Agric. Cria Invest. Pesq., Caracas, $1(2): 38-93$.

SKORNYAKOV, V. I. 1964. Determination of the age of some tropical fish. Trudy atlant. nauchno-issled. Inst. ryb. khoz. okeanogr., 11.

THOMAS, R. M. 1983. Back-calculation and time of hyaline ring formation in the otoliths of the pilchard off southwest Africa. S. Afr. J. mar. Sci., 1:3-18.

1984. A method of age determination for the southwest African pilchard Sardinops ocellata. S. Afr. J. mar. Sci., 2:63-70.

VAZZOLER, A. E. A. de M. 1982. Manual de métodos para estudos biológi cos de populações de peixes: reprodução e crescimento. Brasília, CNPq. Programa Nacional de Zoologia. 106p.
VAZZOLER, A. E. A. de M. ; ROSSI-WONGTSCHOWSKI, C. L. D. B. \& BRAGA, F. M. de S. 1982. Estudos sobre estrutura, ciclo de vida e comportamento de Sardinella brasiliensis (Steindachner, 1879), na área entre $22^{\circ} \mathrm{S}$ e $28^{\circ} \mathrm{S}$, Brasil. 2. Determinação da idade individual e crescimento dos otólitos. Bolm Inst. oceanogr., S Paulo, 31(2): 77-84.

CHOWSKI, C. L. D. B. \& BRAGA, F. M de S. 1987. Estudos sobre estrutura, ciclo de vida e comportamento de Sardinella brasiliensis (Steindachner, 1879), na ärea entre $22^{\circ} \mathrm{S}$ e $28^{\circ} \mathrm{S}$, Brasil. 4. Crescimento: aspectos quantitativos. Bolm Inst. oceanogr., S Paulo, 35(1):53-63.

WILLIAMS, T. \& BEDFORD, B. C. 1974. The use of otoliths for age determination. In: Bagenal, T. B., ed. The proceedings of an International Symposium on the Ageing of Fish, held at the University of Reading, on 19 and $20 \mathrm{July}, 1973$. Surrey, Unwin Brothers. p.114-123.

(Received 01-Jan-88; accepted 08-Ju 1-88) 